TORUŃSKIE STUDIA BIBLIOLOGICZNE

2011, nr $1(6)$

Ewa J. Kurkowska

Instytut Informacii Naukowej i Bibliologii Uniwersytet Mikołaja Kopernika w Toruniu e-mail: luka@umk.pl

\title{
Standardy i modele kształcenia umiejętności informacyjnych w szkolnictwie wyższym Część 2: Wybrane modele i standardy europejskie
}

\section{Wprowadzenie}

W związku z tym, że w ostatnich latach problematyce kształcenia umiejętności informacyjnych poświęca się coraz więcej uwagi, coraz liczniej pojawiają się także dokumenty o charakterze standardów, modeli czy wytycznych. W poprzednim numerze „Toruńskich Studiów Bibliologicznych" ${ }^{11}$ zaprezentowano najważniejsze propozycje światowe w tym zakresie. W niniejszym artykule zostaną krótko omówione wybrane inicjatywy europejskie, tj. te wypracowane w konkretnych państwach lub - jak w przypadku Niemiec - krajach związkowych. Ponieważ wytyczne angielskiego Stowarzyszenia Bibliotek Narodowych i Akademickich (Society of College, National and University Libraries, SCONUL) zostały już opisane w pierwszej części artykułu dedykowanej standardom kształcenia, nie będą one omawiane w tej części tekstu.

Wszystkie zaprezentowane poniżej lokalne standardy i modele w jakimś stopniu odwołują się do tych o charakterze międzynarodowym. Są jednak dowodem na to, że europejskie środowiska bibliotekarskie żywo interesują się problematyką kształtowania kompetencji informacyjnych

${ }^{1}$ E. J. Kurkowska, Standardy i modele kształcenia umiejętności informacyjnych w szkolnictwie wyższym. Część 1: Modele i standardy o zasięgu międzynarodowym, „Toruńskie Studia Bibliologiczne" 2010, nr 2 (5), s. 83-97. 
i pragną stworzyć modele kształcenia odpowiednie do potrzeb i warunków danego kraju.

\section{Czechy}

7 inicjatywy bibliotekarzy Czeskiej Wyższej Szkoły Technicznej w Pradze L(České Vysoké Učení Technické v Praze) powstała Komisja Ekspercka ds. informacji i umiejętności korzystania z informacji w szkolnictwie wyższym (Odborná komise pro informační vzdělávání a informační gramotnost na vysokých školách, dalej: IVIG). Rozpoczęła ona prace w lutym 2000 r. i skupia biblioteki 15 szkół wyższych z Czech i Moraw, Bibliotekę Narodową (Národní knihovna České republiky), Państwową Bibliotekę Techniczną (Národní technická knihovna) oraz Bibliotekę Morawską (Moravská zemská knihovna), a także Instytut Informacji Naukowej i Bibliotekoznawstwa Uniwersytetu Karola w Pradze (Univerzita Karlova v Praze, Ústav informačních studií a knihovnictví). Podczas swych prac komisja niejednokrotnie wykorzystywała osiągnięcia w zakresie information literacy Czeskiej Wyższej Szkoły Technicznej. Obecnie IVIG funkcjonuje jako jedna z komisji Stowarzyszenia Bibliotek Szkół Wyższych (Asociace knihoven vysokých škol).

Jednym z celów IVIG było opracowanie standardów, które mogłyby pomóc w implementowaniu elementów edukacji informacyjnej przez biblioteki szkół wyższych. Standardy te zostały przygotowane w 2007 r., a przedstawiono je m.in. w publikacji Koncepce informačního vzdělávání na vysokých školách v České republice: doporučující materiál Asociace knihoven vysokých škol $\check{C} R^{2}$. Tworząc standardy, wspierano się definicją alfabetyzacji funkcjonalnej przygotowaną w ramach międzynarodowego projektu IALS/SIALS ${ }^{3}$, w którym została ona określona jako „zdolność do aktywnego uczestnictwa w świecie informacji”". Alfabetyzacja informa-

${ }^{2}$ Koncepce informačního vzdělávání na vysokých školách v České republice: doporučující materiál Asociace knihoven vysokých škol ČR [on-line]. Praha: Odborná komise IVIG AKVŠ ČR, 2008, 36 s. [dostęp 15 grudnia 2010]. Dostępny w World Wide Web: http:// www.ivig.cz/koncepce.pdf.

${ }^{3}$ IALS/SIALS: International Adult Literacy Survey/Second International Adult Literacy Survey - badania dotyczące stopnia alfabetyzacji funkcjonalnej poszczególnych społeczeństw. Rozpoczęto je w 1994 r. i w sumie wzięły w nich udział 23 kraje.

${ }^{4}$ Highlights from the Second Report of the International Adult Literacy Survey. Literacy Skills for the Knowledge Society [on-line]. National Adult Literacy Database [dostęp 15 grudnia 2010]. Dostępny w World Wide Web: http://www.nald.ca/FULLTEXT/nls/ ials/ialsreps/ialsrpt2/ials2/highE.pdf. 
cyjna jest rozumiana jako alfabetyzacja funkcjonalna w społeczeństwie informacyjnym. Zawiera więc takie komponenty, jak: prose literacy (zdolność lokalizowania i rozumienia informacji w tekście), document literacy (zdolność wyszukania i użycia precyzyjnie zdefiniowanej informacji), numerical literacy (umiejętność pracy z liczbami i grafami), linguistic literacy (zdolność rozumienia i bycia zrozumianym zarówno w języku ojczystym, jak i obcym - zwłaszcza angielskim). Alfabetyzacja informacyjna jest wspierana przez ICT literacy (zdolność do pracy z komputerem i sieciami) i powiązana z problemami etyki i prawa ${ }^{5}$. Standardy budowane na podstawie takiej definicji information literacy mają więc bardzo szeroki zakres i można zaryzykować stwierdzenie, że nie dotyczą tylko wąsko pojmowanej pracy z informacją, ale całego procesu badawczego. Co ważne, są one tak skonstruowane, że można je zastosować dla różnych kierunków i przedmiotów nauczania - o specyficznych potrzebach i właściwościach. Uwzględniając różnorodne potrzeby poszczególnych dyscyplin i zakresów studiów, czeskie standardy są jednocześnie bardzo uniwersalne. Są one wynikiem współpracy specjalistów, bibliotekarzy i nauczycieli, a ich struktura jest dostosowana do potrzeb szkolnictwa wyższego. Standardy te ustalają zakres wiedzy, zdolności i umiejętności każdego studenta szkoły wyższej przygotowanego informacyjnie, ale dotyczą tylko jego studiów i pracy zawodowej z nimi związanej. Wyodrębniono sześć standardów, które określają następujące kompetencje:

1. Student jest w stanie zrozumieć specjalistyczne teksty z zakresu swych studiów, przedstawić ich główne założenia i samodzielnie pisać podobne teksty, wykorzystując do tego wyniki badań pochodzące z różnych źródeł informacji, które cytuje, respektując prawo autorskie i zachowując zasady tworzenia bibliografii.

2. Student zna i wykorzystuje kluczowe dla swojego kierunku studiów źródła informacji, potrafi znaleźć relewantną informację, wykorzystując podstawowe metody wyszukiwawcze, szanując przy tym prawo i zasady etyki. Student potrafi również zorganizować i zachować informację różnych typów i formatów do dalszego wykorzystania w swojej zawodowej karierze.

3. Student wykorzystuje źródła informacji numerycznej i technicznej, odnajduje i przetwarza numeryczne i techniczne dane i używa ich w swojej pracy.

5 I. Białecki, Alfabetyzm funkcjonalny, „Nowa Res Publica” 1996, nr 6, s. 69-70. 
4. Student sprawnie posługuje się swoim ojczystym językiem - zarówno w mowie, jak i piśmie. Ponadto zna oraz używa terminologii związanej ze swoim zakresem studiów zarówno w języku ojczystym, jak i obcym - zwłaszcza angielskim - na takim poziomie, który jest niezbędny do pracy ze źródłami informacji i komunikacji w społeczności z danej dziedziny.

5. Student używa powszechnie dostępnej technologii informacyjnej i komunikacyjnej, koniecznej do wyszukiwania, przetwarzania i prezentowania informacji (różnych typów i formatów) związanej z jego studiami i przyszłą pracą zawodową.

6. Student jest świadomy moralnych i prawnych aspektów wykorzystywania informacji i pracy z informacją. Postępuje zgodnie z zasadami etyki i prawami autorskimi ${ }^{6}$.

\section{Niemcy}

Drzez Sieć do spraw Kompetencji Informacyjnych Badenii-Wirtembergii (Netzwerk Informationskompetenz Baden-Württemberg, NIK-BW), która wspiera biblioteki szkół wyższych oraz biblioteki regionalne (Landesbibliotheken) z Badenii-Wirtembergii w ich działaniach na rzecz rozwoju szkoleń dotyczących kształcenia kompetencji informacyjnych, zostały przygotowane wytyczne do kształcenia kompetencji informacyjnych dla studiujących (niem. Standards der Informationskompetenz für Studierende $e^{7}$. Przy tworzeniu standardów wykorzystano doświadczenia amerykańskie. Ich struktura przypomina dokument Stowarzyszenia Bibliotek Akademickich i Naukowych USA (Association of College and Research Libraries, dalej: ACRL) ${ }^{8}$, który został przetłumaczony na język niemiecki przez Benno Homanna w 2002 r. Podobnie jak w propozycji amerykańskiej, w Standards der Informationskompetenz für Studierende przedstawiono 5 standardów, wskaźniki osiągnięć oraz konkretne

${ }^{6}$ Koncepce informačního vzdělávání na vysokých školách...

7 Standards der Informationskompetenz für Studierende [on-line]. Mannheim: Netzwerk Informationskompetenz Baden-Württemberg (NIK-BW), 2006, 7 s. [dostęp 15 grudnia 2010]. Dostępny w World Wide Web: http://www.informationskompetenz.de/fileadmin/user_upload/Standards_der_Inform_88.pdf.

${ }^{8}$ Information Literacy Competency Standards for Higher Education [on-line]. Chicago: American Library Association, 2000, 20 p. [dostęp 15 grudnia 2010]. Dostępny w World Wide Web: http://www.ala.org/ala/mgrps/divs/acrl/standards/standards.pdf. 
kompetencje. W porównaniu do amerykańskich, niemieckie standardy są bardziej nastawione na realizowanie kształcenia umiejętności informacyjnych przez biblioteki. Jest to zauważalne zwłaszcza w wykazie kompetencji. Stąd - pomimo pewnych podobieństw do standardów ACRL - nie można ich uznać za wierne odwzorowanie.

Według Standards der Informationskompetenz für Studierende przygotowany informacyjnie student:

- potrafi zdefiniować i wyartykułować swoją potrzebę informacyjną,

- potrafi odnaleźć odpowiednią informację w efektywny sposób,

- umie ocenić informacje i ich źródła oraz dokonać wyboru w zależności od potrzeb,

- potrafi efektywnie przetworzyć zdobytą informację i przedstawić ją za pomocą odpowiednich środków technicznych i uwzględniając przy tym odbiorców,

- jest świadomy swojej odpowiedzialności w zakresie wykorzystywania informacji 9 .

Tak sformułowane standardy mają dość uniwersalny charakter mogą być stosowane zarówno w procesie kształcenia ogólnego, jak i specjalistycznego osób początkujących oraz bardziej zaawansowanych. Odpowiednio przygotowane wskaźniki osiągnięć mogą być pomocne przy tworzeniu własnego programu kształcenia umiejętności informacyjnych przez różne biblioteki.

Obok wspomnianych standardów w Niemczech pojawiło się jeszcze klika innych propozycji. Jedną z nich były przygotowane w Północnej Westfalii i opublikowane w 2003 r. standardy kształcenia kompetencji informacyjnych w szkole wyższej (niem. Standards für die Vermittlung von Informationskompetenz an der Hochschule ${ }^{10}$ ). Dotyczyły one jednak przede wszystkim stworzenia odpowiednich warunków organizacyjnych do nauczania informacyjnego. Innym przykładem może być zestaw wytycznych związanych z kształceniem umiejętności informacyjnych opracowany dla bibliotek bawarskich ${ }^{11}$. Podobnie jak w poprzednim przypadku, jest on w głównej mierze zorientowany na stworzenie ram organizacyjnych kształcenia kompetencji informacyjnych.

9 Standards der Informationskompetenz für Studierende...

${ }^{10}$ A. Nilges, M. Reessing-Fidora, R. Vogt, Standards für die Vermittlung von Informationskompetenz an der Hochschule, „Bibliotheksdienst” 2003, H. 4, s. 463-465.

${ }^{11}$ F. Franke, Mit Informationskompetenz zum (Studien-)Erfolg. Die bayerischen Universitäts- und Hochschulbibliotheken beschließen Standards für die Durchführung von Informationskompetenz-Veranstaltungen, „Bibliotheksdienst” 2009, H. 7, s. 758-763. 


\section{Finlandia} Winlandii prace nad wypracowaniem standardów z zakresu inforw ramach projektu „Standaryzacja zarządzania kompetencjami informacyjnymi 2001-2003" (ang. Standardizing the management of the information literacy 2001-2003) przetłumaczono i opublikowano w Internecie w 2001 r. standardy ACRL ${ }^{12}$. Jednak na potrzeby szkolnictwa wyższego Finlandii nie zaadaptowano ich tak jak np. w Australii, lecz korzystając z dorobku ACRL, starano się wypracować własną drogę, dostosowując je do fińskiego systemu szkolnictwa wyższego. Było to o tyle ważne, że sam termin information literacy jest w Finlandii dwuznaczny i nie jest powszechnie akceptowany. Z drugiej strony, należało dostosować wszelkie zabiegi do tzw. Procesu Bolońskiego (stworzenie 3-stopniowego systemu kształcenia wyższego). Prace nad stworzeniem modelu czy standardu kształcenia umiejętności informacyjnych w fińskich szkołach wyższych przebiegały w dobrym klimacie, jaki powstał w Finlandii wokół idei information literacy. Ich wynikiem było m.in. opracowanie Suositus yliopistoille informaatiolukutaidon oppiainesten sisallyttamiseksi uusiin tutkintorakenteisiin $^{13}$ - wytycznych dla uniwersytetów w sprawie włączenia kompetencji informacyjnych w nową strukturę kształcenia. W dokumencie tym przyjęto, że każda osoba w trakcie studiów powinna posiąść takie umiejętności informacyjne, aby sprawnie funkcjonować w społeczeństwie i kształcić się ustawicznie. Kompetencje te powinny być zgodne z międzynarodowymi standardami opartymi na Information Literacy Competency Standards for Higher Education. Do umiejętności tych należą:

- określenie zakresu potrzeby informacyjnej,

- efektywne i skuteczne dotarcie do potrzebnej informacji,

- krytyczna ocena informacji i jej źródła oraz włączenie nowej informacji w zasób własnej wiedzy,

- efektywne wykorzystanie informacji w domu, nauce i pracy,

12 A. Juntunen, A. Lehto, J. Saarti, J. Tevaniemi, Supporting Information Literacy Learning in Finnish Universities - Standards, Projects, Educating Online, [w:] Information Literacy: International Perspectives, ed. by J. Lau, München 2008, s. 117.

${ }_{13}$ Suositus yliopistoille informaatiolukutaidon oppiainesten sisallyttamiseksi uusiin tutkintorakenteisiin [on-line]. Helsinki: Helsingin yliopisto, 2004, 3 s. [dostęp 15 grudnia 2010]. Dostępny w World Wide Web: http://www.helsinki.fi/infolukutaito/ILopetus/IL_ suositusteksti.pdf. 
- zrozumienie ekonomicznych, prawnych i społecznych aspektów korzystania z informacji oraz użycie jej w sposób etyczny i legalny.

W wytycznych określono również konieczność kształcenia umiejętności informacyjnych na trzech etapach:

- etap I: nowo przyjęci studenci powinni być kształceni w ramach obowiązkowych przedmiotów, np. związanych z technologiami informacyjno-komunikacyjnymi, a za realizację tego nauczania powinni odpowiadać bibliotekarze,

- etap II: bachelor - szkolenia w zakresie information literacy powinny być zintegrowane z proseminariami i seminariami,

- etap III: master - szkolenia w zakresie information literacy powinny być zintegrowane z seminariami magisterskimi. Sposób realizacji zależy od uczelni, ale powinno się uwzględnić współpracę z biblioteką.

Ponadto zostały przedstawione umiejętności, jakie powinien nabyć każdy student na konkretnym etapie studiów ${ }^{14}$.

\section{Francja}

Swego rodzaju model kształcenia umiejętności informacyjnych został zaprezentowany we francuskim dokumencie Maîtrise de l'information des étudiants avancés (master et doctorat). Eléments pour une formation ${ }^{15}$. Jak wskazuje tytuł, został on opracowany na potrzeby studiów magisterskich i doktoranckich. Jest wynikiem spotkania grupy roboczej FORMIST $^{16}$, obradującej w czerwcu 2006 r., i pracy kilkudziesięciu osób, która trwała do października 2006 r. Głównym celem dokumentu jest wskazanie problemów i pojęć, które mogłyby być przedstawione w ramach szkoleń dla studentów. Zestaw zagadnień nie ma charakteru obligatoryjnego

${ }^{4}$ Tamże.

${ }^{15}$ Maîtrise de l'information des étudiants avancés (master et doctorat). Éléments pour une Formation [on-line]. ENSSIB. Bibliothèque numérique [dostęp 15 grudnia 2010]. Dostępny w World Wide Web: http://www.enssib.fr/bibliotheque-numerique/document-1914.

16 FORMIST (Formation à l'information scientifique et technique) to utworzony w 1999 r. dział ENSSIB (francuska narodowa szkoła bibliotekoznawstwa i informacji naukowej powstała w 1992 r. z przekształcenia ENSB - Narodowej Szkoły Bibliotekarzy) zajmujący się gromadzeniem i dostarczaniem materiałów szkoleniowych dla bibliotek. Podaję za: Présentation du service FORMIST [on-line]. ENSSIB [dostęp 15 grudnia 2010]. Dostępny w World Wide Web: http://www.enssib.fr/formist. 
- jest jedynie pomocą dla osób prowadzących takie szkolenia, które można kształtować odpowiednio do potrzeb. W dokumencie wyodrębniono pięć grup zagadnień:

- kultura informacyjna (information literacy),

- znajomość informacji naukowej,

- wyszukiwanie informacji,

- analiza i wykorzystanie informacji,

- przygotowanie i formatowanie informacji.

Całość została przedstawiona w formie tabeli, w której zaznaczono też, dla jakiego poziomu studentów przeznaczone są wybrane zagadnienia (1 rok studiów magisterskich, 2 rok studiów magisterskich, studia doktoranckie), kategorię treści (wiedza typu know-how, wiedza teoretyczna, pytania/dyskusja), dodatkowe zalecenia odnośnie do realizacji. Przy każdym z pięciu podstawowych zagadnień przedstawiono szczegółowe tematy, które mogą być realizowane w zależności od potrzeb i poziomu studiów ${ }^{17}$.

\section{Polskie rozwiq̨zania}

Dolskie środowisko bibliotekarskie, jak do tej pory, nie wypracowało wspólnych standardów w zakresie przygotowania informacyjnego studentów. Pewne próby zostały podjęte jedynie przez biblioteki uczelni medycznych. Propozycje tego typu standardów zostały przedstawione podczas 25. Jubileuszowej Konferencji Problemowej Bibliotek Medycznych, zorganizowanej pod hasłem „Kształcenie użytkowników naukowej informacji medycznej - koncepcje i doświadczenia" w 2006 r. w Lublinie i Kazimierzu Dolnym. Zawierały one zestaw czterech następujących standardów:

1. Użytkownik zna swoje potrzeby w zakresie korzystania z informacji medycznej i umie je sprecyzować.

2. Użytkownik biblioteki medycznej umie dotrzeć do potrzebnej informacji i ją pozyskać.

3. Użytkownik biblioteki medycznej krytycznie ocenia uzyskane informacje.

${ }^{17}$ Maîtrise de l'information... 
4. Użytkownik biblioteki medycznej wykorzystuje wyselekcjonowane informacje do tworzenia i upowszechniania nowej wiedzy ${ }^{18}$.

Każdy ze standardów został wzbogacony o zestaw szczegółowych kompetencji pomagających go realizować.

Jak wspomniano, ciągle brakuje standardów przygotowanych z myślą o wszystkich bibliotekach szkół wyższych. Z pewnością jest to częściowo związane z ograniczonym zainteresowaniem koncepcją information literacy w Polsce. Polskie biblioteki akademickie prowadzą oczywiście działalność dydaktyczną, ale w dużej mierze są to tradycyjne szkolenia biblioteczne, które nie przystają już do potrzeb współczesnego szkolnictwa i społeczeństwa.

Wydaje się, że taka sytuacja nie wynika tylko z braku zainteresowania ze strony bibliotekarzy, ale również z faktu, że bibliotekarze akademiccy nadal nie są w Polsce traktowani jak partnerzy przez przedstawicieli poszczególnych wydziałów ${ }^{19}$ - mimo że w świetle obowiązującej Ustawy „Prawo o szkolnictwie wyższym” bibliotekarze dyplomowani (a tych wśród personelu bibliotek akademickich jest całkiem sporo) mają status nauczycieli akademickich. Chlubnym wyjątkiem są tu, jak wspomniano, biblioteki szkół medycznych.

Skoro w Polsce w środowisku bibliotekarskim nie wypracowano żadnych standardów dotyczących kształcenia informacyjnego w uczelniach wyższych, to czy takich standardów nie ma w ogóle? W pewnym sensie istnieją. Dla każdego z kierunków opracowano standardy kształcenia. Analizując je, można zauważyć, że wynikiem studiów ma być m.in. zdobycie przez studentów kompetencji informacyjnych.

To, co jest szczególnie zauważalne, to fakt, że standardy kształcenia wyższego w zakresie przygotowania informacyjnego odwołują się przede wszystkim do umiejętności narzędziowych, związanych z technologią informacyjną. W większości standardów kształcenia dla poszczególnych

${ }^{18}$ A. Grygorowicz, E. Kraszewska, Propozycje standardów w zakresie edukacji użytkowników polskich bibliotek medycznych. W: 25. Jubileuszowa Konferencja Problemowa Bibliotek Medycznych. Kształcenie użytkowników naukowej informacji medycznej - koncepcje i doświadczenia. Lublin-Kazimierz Dolny, 12-14 czerwca $2006 r$. [on-line]. [Warszawa]: Stowarzyszenie Bibliotekarzy Polskich, Komisja Wydawnictw Elektronicznych, 2006 (EBIB Materiały konferencyjne, nr 14) [dostęp 15 grudnia 2010]. Dostępny w World Wide Web: http://www.ebib.info/publikacje/matkonf/25kpbm/grygorowicz_kraszewska_1.php.

${ }_{19} \mathrm{Na}$ ten fakt zwracali uwagę obradujący podczas konferencji w Bibliotece Politechniki Łódzkiej w 2008 r.

${ }^{20}$ Ustawa z dnia 27 lipca 2005 r. „Prawo o szkolnictwie wyższym”, Dz.U. 2005, nr 164, poz. 1365, art. 108. 
kierunków odnajdujemy zapis dotyczący wymagań odnośnie do programów nauczania:

Treści kształcenia w zakresie technologii informacyjnej: podstawy technik informatycznych, przetwarzanie tekstów, arkusze kalkulacyjne, bazy danych, grafika menedżerska i/lub prezentacyjna, usługi w sieciach informatycznych, pozyskiwanie i przetwarzanie informacji [wyróżnienie - E. J. K.] - powinny stanowić co najmniej odpowiednio dobrany podzbiór informacji zawartych w modułach wymaganych do uzyskania Europejskiego Certyfikatu Umiejętności Komputerowych (ECDL - European Computer Driving Licence) ${ }^{21}$.

Jest to zawężenie problemu i nie przystaje do współczesnego rozumienia information literacy.

\section{Podsumowanie}

Modele i standardy zaprezentowane powyżej nie stanowią kompletnego wyboru. Tego typu inicjatyw jest coraz więcej i włączają się w nie środowiska bibliotekarskie kolejnych krajów europejskich. Te, które zostały przedstawione, odwołują się do różnych kwestii związanych z kształtowaniem kompetencji informacyjnych: z jednej strony zawierają zestawy pożądanych umiejętności, z drugiej - próbują określić ramy organizacyjne funkcjonowania szkoleń z zakresu information literacy. Wszystkie modele są też formułowane bardzo ogólnie i dzięki temu są bardziej elastyczne - można je zastosować w różnych instytucjach i do różnych potrzeb.

Warto zwrócić uwagę na jeszcze jedną kwestię, która została wyartykułowana w wytycznych fińskich: otóż kształcenie kompetencji informacyjnych ma zostać wpisane w Proces Boloński. Coraz więcej krajów wydaje się iść w tym kierunku, by różnego rodzaju szkolenia z zakresu information literacy zostały włączone do programów studiów. Pro-

${ }^{21}$ Standardy kształcenia dla poszczególnych kierunków studiów i poziomów kształcenia. Biuletyn Informacji Publicznej Ministerstwa Nauki i Szkolnictwa Wyższego [on-line] 2007-2010 [dostęp 15 grudnia 2010]. Dostępny w World Wide Web: http://www.bip. nauka.gov.pl/bipmein/index.jsp?place=Lead07\&news_cat_id=117\&news_id=982\&layout $=1 \&$ page $=$ text. 
ces Boloński to również dostosowanie systemów edukacji wyższej do wspólnych, europejskich wymogów. W Polsce na ten problem odpowiedziały wprost jedynie biblioteki szkół medycznych, co nie znaczy, że nic się w tej kwestii nie dzieje. Jednak ten temat wymaga odrębnych, pogłębionych badań.

\section{Information literacy standards and models in Higher Education. Part 2: Selected European standards and models}

Abstract

The article presents selected information literacy standards and models for students prepared by European library organizations. There are standards from Czech Republic, Germany, Finland, France and Poland. All of them include information skills sets and their indicators, some of them include also some organizational hints. They are general in nature, so they can be applied to various types of schools and courses of education. 